\title{
FAMILY AND INDIVIDUAL DIETARY AND LIFESTYLE HABITS AS PREDICTORS OF BMI AND KIDMED SCORE IN GREEK AND IMMIGRANT PRESCHOOLERS
}

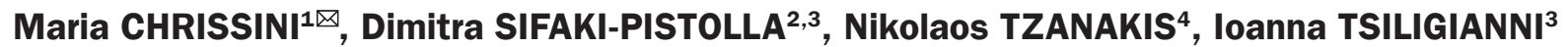 \\ ${ }^{1}$ Department of Social Medicine, Faculty of Medicine, University of Crete, Crete, Greece \\ ${ }^{2}$ Clinic of Social and Family Medicine, Faculty of Medicine, University of Crete, Crete, Greece \\ ${ }^{3}$ Health Planning Unit, Department of Social Medicine, Faculty of Medicine, University of Crete, Crete, \\ Greece \\ ${ }^{4}$ Department of Thoracic Medicine, Faculty of Medicine, University of Crete, Crete, Greece \\ Received 3 Oct 2019, Accepted 06 Nov 2019 \\ hitps://doi.org/10.31688/ABMU.2019.54.4.07
}

\section{Abstract}

Introduction: in our multicultural society the global pandemia of obesity consists in the severest form of overweight, affecting young children, with individual and parental dietary and lifestyle factors being associated with $\mathrm{OW} / \mathrm{OB}$ among preschoolers.

The objective of the study was to assess the parental dietary and lifestyle trajectories that predict and determine native Greek and immigrant preschoolers' BMI and KIDMED score.

Material and methods: 578 guardian parents and 578 preschoolers (5-6 year-old), both native Greeks $(n=451)$ and other nationalities $(n=127)$ participated in this cross-sectional study. The Food Frequency Questionnaire and KIDMED scores were utilized.

Results: Significantly high level of concordance of guardian parents' and preschoolers' dietary habits (Spearman's rho $=0.94, \mathrm{R}^{2}=0.91, \mathrm{p}<0.001$ ) was revealed. The strongest predictors significantly increasing BMI in preschoolers $(\mathrm{p}<0.05)$ were: low levels of

\section{Résumé}

Les habitudes alimentaires et de style de vie familiale et individuelle en tant que prédicteurs de IMC et de score KIDMED chez les préscolaires grecs et immigrants

Introduction: Dans notre société multiculturelle, la pandémie mondiale d'obésité constitue la forme la plus sévère de surpoids qui touche les jeunes enfants; les facteurs alimentaires et le style de vie individuel et parentel sont associés à la survenue de TA / OB chez les enfants d'âge préscolaire.

L'objectif de l'étude était d'évaluer les trajectoires alimentaires et le style de vie des parents qui permettent de prédire et de déterminer l'IMC et le score de KIDMED pour les enfants grecs et immigrés.

Matériel et méthodes: 578 parents gardiens et 578 enfants d'âge préscolaire (âgés de 5 à 6 ans), des Grecs autochtones $(\mathrm{n}=451)$ et d'autres nationalités $(\mathrm{n}=127)$ ont participé à cette étude transversale. Des 
KIDMED score, low frequency of removing fat from meat prior eating, low parental frequency of following Mediterranean Diet. Contrariwise, regular family's breakfast and brunch consumption, high frequency of consuming vegetables or fruits and physically active parents who control preschoolers' diet, were predictors of diminishing the risk of high BMI in children. Child's increased physical activity and parents' frequency of following the Mediterranean Diet were found to decrease the risk of low KIDMED score in preschoolers.

Conclusions: Both Greek and other nationalities' guardian parents' lifestyle characteristics, dietary habits and choices act as determinants either reinforcing or aggravating preschoolers' health outcomes. Families should promote optimal dietary habits for better health outcomes.

Keywords: preschoolers, immigrants, BMI, KIDMED score, dietary habits, Mediterranean Diet.

\author{
Abbreviations list: \\ $\mathrm{WHO}=$ World Health Organization \\ $\mathrm{OW} / \mathrm{OB}=$ Overweight $/$ Obesity \\ $\mathrm{MD}=$ Mediterranean Diet \\ SES $=$ Socio-Economic Status \\ $\mathrm{BMI}=$ Body Mass Index \\ $\mathrm{PA}=$ Physical Activity \\ MVPA = Moderate to Vigorous Physical Activity \\ L-VPA = Light to Vigorous Physical Activities \\ FFQ = Food Frequency Questionnaire \\ KIDMED $=$ Mediterranean Diet Quality Index
}

\section{INTRODUCTION}

The World Health Organization (WHO) illustrates the global pandemia of obesity as the severest form of overweight, affecting children both in developed and developing countries. ${ }^{1} \mathrm{~A}$ worldwide increase in levels of overweight/obesity (OW/OB) in preschool age has been reported, while 2020 projections predict a rise to $9.1 \% .^{2}$ Countries of the Mediterranean region and the British islands report the highest rates of overweight/obesity in preschoolers, while the lowest scores are reported in central, middle, eastern and northern European countries. ${ }^{3}$

The etiology of early childhood OW/OB, which still remains an understudied issue, ${ }^{4}$ is multidimensional and encompasses genetic (i.e. gender, age) and environmental factors (i.e. ethnicity, socio-economic status, parental weight status, parental lifestyle and dietary intake habits). ${ }^{5,6}$ Parental BMI scores are significantly linked with child's BMI and levels of adherence to the Mediterranean Diet (MD); ${ }^{7}$ an questionnaires sur la fréquence des repas et les scores KIDMED ont été utilisés.

Résultats: Un niveau de concordance significativement élevé entre les habitudes alimentaires des parents gardiens et des enfants d'âge préscolaire (rho de Spearman $=0,94, R 2=0,91, p<0,001)$ a été révélé. Les prédicteurs les plus puissants augmentant de manière significative l'IMC chez les enfants d'âge préscolaire ( $\mathrm{p}$ $<0,05)$ étaient: les faibles niveaux du score KIDMED, la faible fréquence d'élimination des graisses de la viande avant l'alimentation, la faible fréquence parentale de la diète méditerranéenne. En revanche, la consommation régulière du petit-déjeuner et du brunch en famille, la consommation fréquente de légumes ou de fruits et les parents physiquement actifs qui contrôlent le régime alimentaire des enfants d'âge préscolaire étaient des prédicteurs de la diminution du risque d'IMC élevé chez les enfants. L'activité physique accrue de l'enfant et la fréquence avec laquelle les parents suivent le régime méditerranéen diminuent le risque du faible score KIDMED chez les enfants d'âge préscolaire.

Conclusions: Les caractéristiques du mode de vie, les habitudes et les choix alimentaires des parents gardiens, grecs et d'autres nationalités, jouent un rôle déterminant dans le renforcement ou l'aggravation des résultats pour la santé des enfants d'âge préscolaire. Les familles devraient promouvoir des habitudes alimentaires optimales pour de meilleurs résultats en matière de santé.

Mots-clés: enfants d'âge préscolaire, immigrants, IMC, score KIDMED, habitudes alimentaires, régime méditerranéen.

important health-promoting pattern for children ${ }^{8}$ measured by the Mediterranean Diet Quality Index for children (KIDMED score). Preschool children in the Mediterranean countries of the EU, however, exhibited low adherence to the Mediterranean-like diet, which in turn was associated with early rates of OW/ OB. ${ }^{9,10}$ Although OW/OB rates are more prevalent in low Socio-Economic Status (SES) and ethnic minority groups ${ }^{11}$ the relationship of these socio-demographic variables with parental feeding practices and culture ${ }^{12}$ is still under-examined.

Apart from parental dietary and overall lifestyle, additional individual-level behaviors could directly affect preschoolers' BMI. For instance, preschoolers are believed to be highly physically active, ${ }^{13}$ nevertheless, they are highly susceptible to early adoption of obesogenic lifestyles, due to their engagement in fairly low levels of moderate to vigorous physical activity (MVPA). ${ }^{14}$ Furthermore, longer periods of TV viewing have been identified as an important modulator of the risk of greater BMI and OW/OB in preschoolers. ${ }^{15,16}$ 
Although $\mathrm{OW} / \mathrm{OB}$ rates in preschoolers in Greece are reported ${ }^{17}$ among the highest worldwide (17.5\% and $16.2 \%$, respectively), empirical data on the individual and parental dietary and lifestyle habits of preschoolers of different ethnicity and their impact on children's BMI are limited. ${ }^{4,18}$ The present study constitutes the first cross-sectional study that seeks to fill the gap in the current literature by identifying early determinants of early childhood overweight/ obesity in both native Greek and ethnic minority preschoolers in Greece.

THE PRIMARY OBJECTIVE OF THE STUDY was to investigate the individual and parental dietary and lifestyle factors associated with OW/OB among preschoolers attending kindergartens in Attica region, Greece. Additional objectives were set to further explore level of potential correlation of guardian parents' and preschoolers' dietary habits, to identify predictors of high and low preschoolers' BMI, as well as predictors of low KIDMED score.

\section{Material AND Methods}

\section{Study design and participants}

This cross-sectional study was conducted in Attica region (largest administrative region in Greece, including the capital city), during the school year 2016-2017. The study population consisted of preschoolers aged 5 to 6 years, attending public kindergarten and their guardian parent.

The terms ethnic group or population were determined as „a group of people smaller in number than the majority categories, who by their customs, language, race, values, and group interests differ from the majority population". ${ }^{19}$ The framework of ethnicity in our study, similarly to other cross-sectional studies, ${ }^{20}$ was defined according to the preschoolers' and their guardian parents' country of birth. Specifically, participants were considered of non-Greek ethnicity if: (1) born outside Greece and at least one parent born outside Greece (i.e. first generation); or (2) born in Greece, but both parents born outside Greece (i.e. second generation) and migrated in Greece.

Several inclusion criteria were formed as follows: a) permanent residents in Attica, b) registered in the selected kindergartens, c) speaking and comprehending the Greek language. Preschoolers not attending the extended educational program (from 8.15 a.m. to 16 p.m.) were excluded in order to ensure that all participants (preschoolers) would eat lunch during school hours. The total number of participants consisted of five hundred and seventy-eight $(\mathrm{n}=578)$ preschoolers, five hundred and seventy-eight $(\mathrm{n}=578)$ guardian parents, both native Greeks $(\mathrm{n}=451)$ and other nationalities $(\mathrm{n}=127)$ from 63 public Kindergarten schools in
36 municipalities within Attica region. Schools were situated both at the suburbs and in the center of capital city (Athens) and were randomly selected from a list provided by the Ministry of Education.

Additional information on study design and sampling is presented in another paper which is currently under publication.

\section{Ethical approval}

The study was designed according to the principles of Helsinki declaration (1989) and approved by the Research Department of the Education Institute of the Hellenic Ministry of Education (ethical approval F15/1774/222145/2016). Participants (guardian parents) and kindergartens were extensively informed for the purposes and processes of this study and provided written consent forms and a written approval (a/a: 03/10/2016), respectively.

\section{Anthropometrical \& Lifestyle Measurements}

Data regarding families' demographic characteristics and profile, such as parent's age, ethnic group, employment status and years of education were collected by the use of the validated Food Frequency Questionnaire (FFQ). ${ }^{21}$ Additional anthropometrical data were obtained by preschoolers' parents, such as current height and body weight of each parent and his/her child. Parents body height (m) and weight $(\mathrm{kg})$ were self-reported and used to calculate parents BMI $(\mathrm{kg} / \mathrm{m} 2)$ and to define parents overweight (BMI $25-29.9 \mathrm{~kg} / \mathrm{m} 2$ ) and obesity (BMI P30 kg/m2), according to the World Health Organization classification for adults. BMI as weight $(\mathrm{Kg})$ ratio to squared height (m2) was calculated for each child. To determine overweight and obesity, BMI percentile and CDC were used. BMI between 85 and 95 percentiles, (for age and sex), was accounted as overweight and greater than 95 is defined as obese.

\section{Evaluation of dietary habits}

Two separate but similarly structured questionnaires were used in preschoolers and parents respectively. These questionnaires were a composition of two validated tools; the Food Frequency Questionnaire (FFQ) ${ }^{21}$ and the Mediterranean Diet Quality Index (KIDMED). ${ }^{8}$ The KIDMED score ${ }^{10}$ measured adherence to the Mediterranean style diet among preschoolers, based on the principles sustaining healthful, Mediterranean-style dietary patterns, as well as on those that do not support the Mediterranean-style dietary pattern. Other aspects of eating behavior were also evaluated, such as eating at least one family meal per day, frequency of eating home-delivered food, breakfast consumption, eating while engaged in other sedentary activities. 
The FFQ was selected as a validated semi-quantitative food frequency questionnaire designed to assess habitual dietary intake in preschool children. ${ }^{22}$ It comprises 118 food items with the following components: food frequency, type of meals during the day (breakfast, morning snack, lunch, afternoon snack, dinner and evening snack), use of dietary supplements, type of fat used for cooking, frequency of meals consumed in restaurants or take away and television viewing during meals.

\section{Physical activity assessment}

Information on guardian parents' and preschoolers' physical activity levels was obtained by a valid, structured Physical Activity Questionnaire (developed by the Rhea Study, University of Crete). ${ }^{23}$ Questions included information on parents' frequency of physical activity (alone or together with their children), type, duration, and intensity of the child's participation in all typical school outdoor organized or non-organized Light to Vigorous Physical Activities (L-VPA).

\section{Statistical analysis}

All tests were two-tailed and performed at $\mathrm{a}=0.05$, in the IBM SPSS 24. Upon testing for distributions by Kolmogorov-Smirnov and binomial chi-square, the majority of variables were found to follow a normal distribution. Descriptive statistics were demonstrated using $\mathrm{N}(\%)$ and Mean (Standard Deviations, SD). Chi-square, Kruskal Wallis and Mann Whitney tests were utilized.

Furthermore, two new variables were created based on parents' and preschoolers' dietary habits, using empirical grouping of dietary habits questions and checking the final grouping by cluster analysis. Lastly, mathematical weights were provided to rank least and best patterns of dietary habits per category (parents or children). Pearson's rho was applied to assess the level of concordance and correlation of these two variables. Two multivariate regression models were developed to predict preschoolers' BMI and low KIDMED score based on preschoolers' and parents' habits.

\section{Results}

\section{Level of concordance of parent's and child's dietary habits}

Figure 1 illustrates the level of concordance of parent's and child's dietary habits utilizing the overall diet score in each group. As observed, dietary patterns presented significant correlation (Pearson's rho $=0.94$, $\mathrm{p}<0.001$ ). More than $90 \%$ of child's dietary habits could be explained by parent's choices $(\mathrm{R} 2=0.91)$. Detailed findings on parent's and child's dietary and lifestyle habits per nationality group are presented in Table 1 and Supplementary Tables S1 and S2.

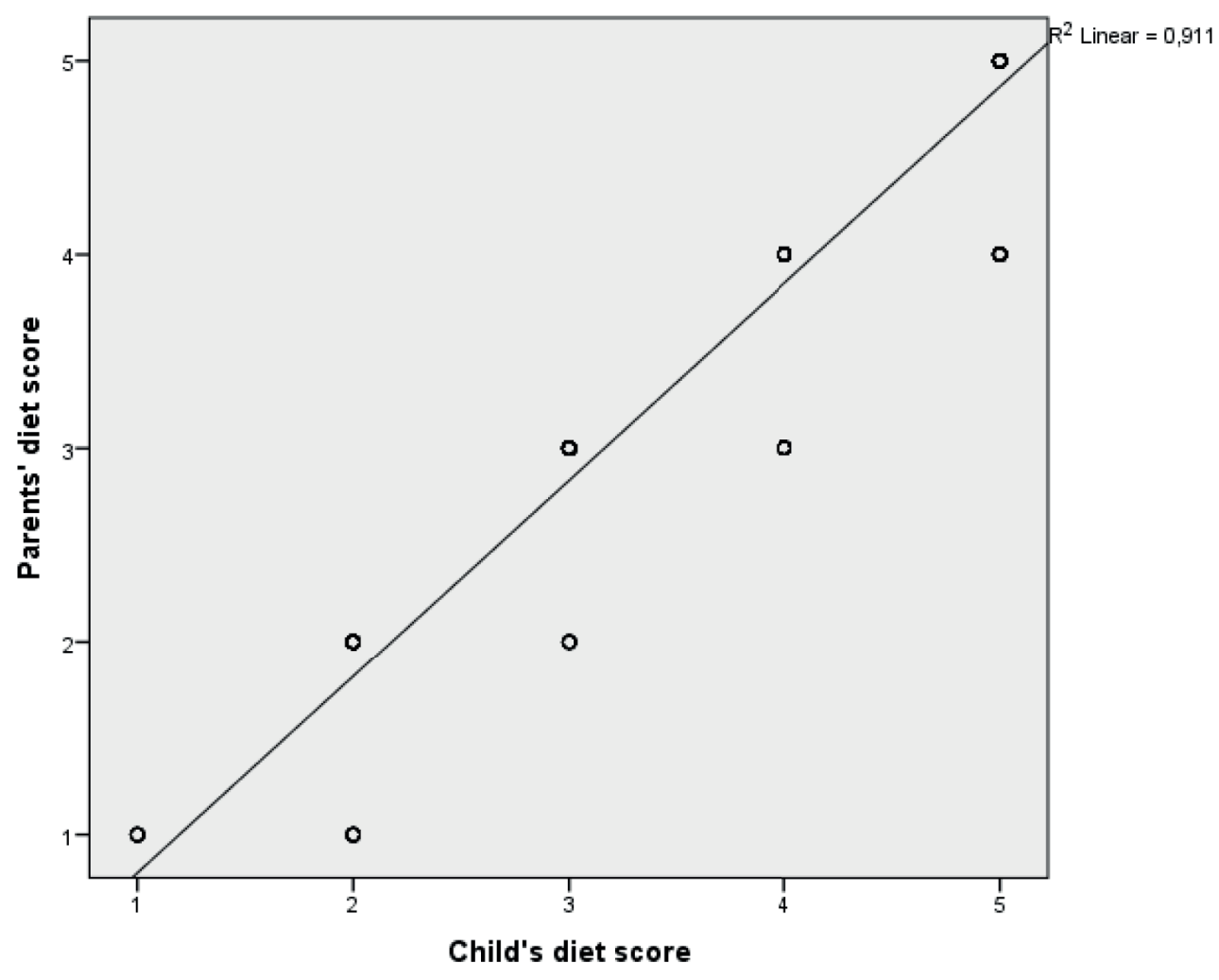

Figure 1: Comparison of parent's and child's dietary patterns 
Table 1. Comparison of dietary and other lifestyle characteristics of the participants of different nationality

\begin{tabular}{|c|c|c|c|}
\hline & \multicolumn{2}{|c|}{$\begin{array}{l}\text { Nationality } \\
\mathrm{N}(\%)\end{array}$} & \multirow[t]{2}{*}{ P value } \\
\hline & $\begin{array}{l}\text { Greeks } \\
N=451\end{array}$ & $\begin{array}{c}\text { Other nationality } \\
\quad N=127\end{array}$ & \\
\hline Parents' frequency of Mediterranean diet & & & $<0.001$ \\
\hline Not at all & $13(2.9)$ & $25(19.8)$ & \\
\hline Rarely & $83(18.5)$ & $53(42.1)$ & \\
\hline Often & $314(70.1)$ & $45(35.7)$ & \\
\hline Very often & $38(8.5)$ & $3(2.4)$ & \\
\hline Parents' breakfast consumption (yes) & $342(75.8)$ & $91(71.7)$ & 0.3 \\
\hline Children's breakfast consumption (yes) & $409(91.1)$ & $109(85.8)$ & 0.08 \\
\hline Parents' brunch consumption (yes) & $301(67.2)$ & $44(34.6)$ & $<0.001$ \\
\hline Children's brunch consumption (yes) & $425(94.2)$ & $105(82.7)$ & $<0.001$ \\
\hline Parents' meal consumption (yes) & $425(94.7)$ & $122(96.1)$ & 0.5 \\
\hline Children's consumption of meal in the afternoon (yes) & $395(87.6)$ & $86(67.7)$ & $<0.001$ \\
\hline Parents' Dinner consumption (yes) & $357(79.2)$ & $111(87.4)$ & 0.03 \\
\hline Children's dinner consumption & $404(89.6)$ & $115(90.6)$ & 0.7 \\
\hline Parents' time of dinner & & & 0.2 \\
\hline Don't eat & $42(9.3)$ & $8(6.3)$ & \\
\hline Not at specific time & $74(16.4)$ & $28(22)$ & \\
\hline Before 20.00 & $70(15.5)$ & $28(22)$ & \\
\hline At 20.00 & $87(19.3)$ & $20(15.7)$ & \\
\hline At 21.00 & $125(27.7)$ & $35(27.6)$ & \\
\hline At 22.00 & $44(9.8)$ & $7(5.5)$ & \\
\hline After 22.00 & $9(2.0)$ & $1(0.8)$ & \\
\hline Children's time of dinner consumption & & & $<0.001$ \\
\hline No dinner & $19(4.2)$ & $2(1.6)$ & \\
\hline No specific hour & $18(4)$ & $18(14.2)$ & \\
\hline Before 20.00 & $144(31.9)$ & $48(37.8)$ & \\
\hline At 20.00 & $193(42.8)$ & $44(34.6)$ & \\
\hline At 21.00 & $70(15.5)$ & $13(10.2)$ & \\
\hline At 22.00 & $7(1.6)$ & $2(1.6)$ & \\
\hline $\begin{array}{l}\text { Parents' frequency of eating at fast food restaurants } \\
\text { (including souvlakery) }\end{array}$ & & & $<0.001$ \\
\hline Never & $104(23.2)$ & $58(45.7)$ & \\
\hline Rarely & $263(58.6)$ & $58(45.7)$ & \\
\hline Often & $82(18.3)$ & $11(8.7)$ & \\
\hline Once/Twice per month & $239(53)$ & $47(37)$ & \\
\hline Children's Frequency of eating at fast food restaurants & & & 0.4 \\
\hline 4 or more times per week & $3(0.7)$ & $2(1.6)$ & \\
\hline $2-3$ times per week & $4(0.9)$ & $1(0.8)$ & \\
\hline Once per week & $76(16.9)$ & $16(12.6)$ & \\
\hline $1-3$ times per month & $162(35.9)$ & $47(37)$ & \\
\hline Less than once per month & $180(39.9)$ & $48(37.8)$ & \\
\hline Never & $26(5.8)$ & $13(10.2)$ & \\
\hline Parents' frequency of consuming vegetables and fruits & & & 0.01 \\
\hline Less than once per week & $7(1.6)$ & - & \\
\hline At least once per week & $41(9.1)$ & $6(4.7)$ & \\
\hline Three/five times per week & $151(33.5)$ & $31(24.4)$ & \\
\hline Every day & $252(55.9)$ & $90(70.9)$ & \\
\hline Children's frequency of consuming vegetables and fruits & & & $<0.001$ \\
\hline Not at all & $63(14)$ & $9(7.1)$ & \\
\hline Once per day & $323(71.6)$ & $82(64.6)$ & \\
\hline
\end{tabular}


Table 1. Comparison of dietary and other lifestyle characteristics of the participants of different nationality (continued)

\begin{tabular}{ccc}
\hline 2-3 times per day & $54(12)$ & $27(21.3)$ \\
\hline More than 3 times per day & $11(2.4)$ & $9(7.1)$ \\
\hline Removing fat from child's meat (prior consumption) & & \\
\hline No & $72(16)$ & $32(25.2)$ \\
\hline Pes & $379(84)$ & $95(74.8)$ \\
\hline Parents controlling child's diet & & 0.02 \\
\hline Rever & $2(0.4)$ & $3(2.4)$ \\
\hline Relatively often & $6(1.3)$ & $6(4.8)$ \\
\hline Often & $49(10.9)$ & $20(15.9)$ \\
\hline Very often & $199(44.1)$ & $49(38.9)$ \\
\hline Parents' years of smoking & $195(43.2)$ & $48(38.1)$ \\
\hline Parents' alcohol consumption (yes) & $16.1(5.5)$ & $12.2(6.2)$ \\
\hline Parents' physical activity (yes) & $150(33.3)$ & 0.03 \\
\hline Watching TV while eating (yes) & $191(42.5)$ & 0.05 \\
\hline Children's physical activity (yes) & $2.7(1.5)$ & 0.004 \\
\hline & $334(74.1)$ & $3.6(2.2)$ \\
\hline
\end{tabular}

Table 2. Multivariate model of predicting high BMI in preschoolers of different nationalities in Greece (Model 1)

\begin{tabular}{cccc}
\hline Predictors & $\beta$ estimate $^{a}$ & Standard Error & P value \\
\hline KIDMED score & -0.8 & 0.2 & $<0.001$ \\
\hline Physical Activity & -0.8 & 0.3 & 0.02 \\
\hline Removing fat from meat prior eating & -0.6 & 0.2 & 0.03 \\
\hline Watching TV while eating & 0.7 & 0.3 & 0.04 \\
\hline Mother's age & 0.4 & 0.03 & 0.03 \\
\hline Parents' BMI & 0.6 & 0.1 & 0.01 \\
\hline $\begin{array}{c}\text { Parents' frequency of following } \\
\text { Mediterranean Diet }\end{array}$ & -0.5 & 0.4 & 0.03 \\
\hline Parents' Smoking habits (pack/years) & 0.2 & 0.1 & $<0.001$ \\
\hline Parents' years of smoking & 0.3 & 0.02 & 0.04 \\
\hline Parents' Alcohol consumption (glasses/week) & 0.1 & 0.03 & 0.03 \\
\hline Parents' Physical Activity & -0.2 & 0.09 & \\
\hline
\end{tabular}

a model adjusted for age, parents' profession, nationality

\section{Predictors of high preschoolers' BMI}

Two core multivariate models were developed to estimate high BMI in children. Table 2 presents the first multivariate model of the joint impact of eleven indicators in preschoolers of different nationalities in Greece. Low levels of KIDMED score $(\beta$ estimate $=-0.8, \mathrm{SE}=0.2)$, low levels of physical activity $(\beta$ estimate $=-0.8, \mathrm{SE}=0.3$ ), removing fat from meat prior eating $(\beta$ estimate $=-0.6, \mathrm{SE}=0.2)$ and parents' low frequency of following $\mathrm{MD}$ ( $\beta$ estimate $=-0.5, \mathrm{SE}=0.4$ ) seem to increase the risk of high child's BMI, significantly (all p<0.05). Moreover, high frequency of watching TV while eating ( $\beta$ estimate $=0.7, \mathrm{SE}=0.3)$, mother's age $(\beta$ estimate $=0.4, \mathrm{SE}=0.03)$ and $\mathrm{BMI}(\beta$ estimate $=$ $0.6, \mathrm{SE}=0.1$ ) also increase the risk, significantly (all $\mathrm{p}<0.05)$. Similarly, higher risk is observed in children whose parents are long-term smokers ( $\beta$ estimate $=0.2$, $\mathrm{SE}=0.1),(\beta$ estimate $=0.3, \mathrm{SE}=0.02)$, alcohol consumers $(\beta$ estimate $=0.1, \mathrm{SE}=0.03)$ and physically inactive $(\beta$ estimate $=-0.2, \mathrm{SE}=0.09)($ all $\mathrm{p}<0.05)$.

In the second multivariate model (Table 3 ), several indicators were identified as significant $(p<0.05)$. Similarly to the first model, the following parents' characteristics were found to increase BMI risk: high BMI and years of smoking, decreased physical activity, low frequency of following the Mediterranean nutritional scheme and removing fat from meat prior eating. In addition to these factors, the latest the time of dinner consumption $(\beta$ estimate $=0.8, \mathrm{SE}=0.2$ ) and the highest the number of meals consumed at 
Table 3. Multivariate model of predicting high BMI

in preschoolers of different nationalities in Greece (Model 2)

\begin{tabular}{cccc}
\hline Predictors & $\beta$ estimate $^{a}$ & Standard Error & P value \\
\hline Removing fat from meat prior eating & -0.5 & 0.1 & 0.02 \\
\hline Consumption of breakfast & -0.9 & 0.1 & $<0.001$ \\
\hline Consumption of brunch & -0.8 & 0.1 & 0.01 \\
\hline Time of dinner consumption & 0.8 & 0.2 & 0.001 \\
\hline $\begin{array}{c}\text { Frequency of eating at fast food restaurants } \\
\text { Frequency of vegetables or fruits consump- } \\
\text { tion jointly with parents }\end{array}$ & 0.7 & 0.1 & 0.02 \\
\hline Parents controlling child's diet & -0.6 & 0.02 & 0.03 \\
\hline Parents' Physical Activity & -0.6 & 0.4 & $<0.001$ \\
\hline Parents' BMI & -0.5 & 0.1 & 0.001 \\
\hline $\begin{array}{c}\text { Parents' frequency of following } \\
\text { Mediterranean Diet }\end{array}$ & 0.5 & 0.2 & 0.03 \\
\hline Parents' years of smoking & -0.6 & 0.03 & $<0.001$ \\
\hline Parents' Physical Activity & 0.4 & 0.01 & 0.04 \\
\hline
\end{tabular}

a model adjusted for age, parents' profession, nationality

fast food restaurants ( $\beta$ estimate $=0.7, \mathrm{SE}=0.1$ ), the greatest is the risk of high BMI in children. On the contrary, consumption of breakfast ( $\beta$ estimate $=-0.9$, $\mathrm{SE}=0.1)$ and brunch $(\beta$ estimate $=-0.8, \mathrm{SE}=0.1)$, high frequency of consuming vegetables or fruits ( $\beta$ estimate $=-0.6, \mathrm{SE}=0.02)$ and physically active parents $(\beta$ estimate $=-0.5, \mathrm{SE}=0.1$ ) seemed to diminish the risk for high BMI in children. Lower risk was also presented when parents control child's diet ( $\beta$ estimate $=-0.6$, $\mathrm{SE}=0.4)$.

\section{Predictors of preschooler's KIDMED score}

Table 4 summarizes the joint effect of low KIDMED score predictors, adjusting for child's age, BMI and nationality. Child's increased physical activity $(\beta$ estimate $=-0.6, \mathrm{SE}=0.3$ ) and parents' frequency of following the Mediterranean Diet ( $\beta$ estimate $=-0.9, \mathrm{SE}=0.03$ ) were observed to decrease the risk for low KIDMED score, while watching TV when eating, increased children's risk of low KIDMED score $(\beta$ estimate $=0.5, \mathrm{SE}=0.08)$. Similar trends were observed to preschoolers whose parents have a high BMI ( $\beta$ estimate $=0.7, \mathrm{SE}=0.01)$ and are long-term smokers $(\beta$ estimate $=0.5, \mathrm{SE}=0.4)$. All $\mathrm{p}<0.05$.

\section{Discussion}

Our study revealed that low levels of parental PA and frequency of following MD, eating out in fast food restaurants, mother's age and child's BMI operate as predictors of high preschoolers' BMI. To the contrary, breakfast, brunch and early dinner consumption, vegetables and fruits intake, removing fat prior eating, parental control of preschoolers' diet have a positive effect on maintaining preschoolers' normal BMI or
Table 4. Multivariate model of predicting low KIDMED score in preschoolers of different nationalities in Greece

\begin{tabular}{cccc}
\hline Predictors & $\beta$ estimate $^{a}$ & $\begin{array}{c}\text { Standard } \\
\text { Error }\end{array}$ & $\begin{array}{c}P \\
\text { value }\end{array}$ \\
\hline $\begin{array}{c}\text { Children's Physical } \\
\text { Activity }\end{array}$ & -0.6 & 0.3 & 0.02 \\
\hline $\begin{array}{c}\text { Watching TV while } \\
\text { eating }\end{array}$ & 0.5 & 0.08 & $<0.001$ \\
\hline Parents' BMI & 0.7 & 0.1 & 0.01 \\
\hline $\begin{array}{c}\text { Parents' frequency } \\
\text { of following } \\
\text { Mediterranean Diet }\end{array}$ & -0.9 & 0.03 & $<0.001$ \\
\hline $\begin{array}{c}\text { Parents' years } \\
\text { of smoking }\end{array}$ & 0.5 & 0.4 & 0.03 \\
\hline
\end{tabular}

a model adjusted for age, BMI, nationality

decreasing obesity/overweight. Additionally, parents and preschoolers frequently following MD, child's increased physical activity were depicted as predictors of positive preschoolers' KIDMED score, whereas, reverse outcome was found with parents with high BMI. Watching TV while eating, parental smoking and alcohol consumption, were found to be predictors negatively associated with preschoolers' BMI and KIDMED score. Lastly, ethnicity seemed to play an integral role on lifestyle trends, yet it had no diverse impact on the under-study outcomes (e.g. child's BMI and adherence to the Mediterranean diet).

\section{Parental characteristics and habits as predic- tors of high preschoolers' BMI}

Considerable evidence supports the fundamental role parents play in shaping the development of child eating habits, behavior ${ }^{24}$ and their weight status. ${ }^{25}$ The current study revealed significantly similar 
dietary habits between parents and preschoolers. These findings presented trends based on a generalized pattern of their habits, concluding on the high impact of parental choices on children.

Low levels of parental physical activity and adherence to the Mediterranean diet

Studies examining the associations between PA and body fat in young children are scarce, ${ }^{26,27}$ and to the best of our knowledge, few studies have estimated the associations between objectively measured PA and BMI in preschoolers. ${ }^{28,29}$ Our study addressed, as well, the strong relationship between high levels of parental physical activity and children's active engagement in physical activities, with the positive, beneficial effect of their lower BMI, a pattern also observed in other studies on preschoolers. ${ }^{30-31}$ Concerning the relationship of the MD with young children's BMI, although the relevant epidemiological studies do not always show the same protective effect, it could be claimed that higher adherence to the MD reduces the risk of children's OW/OB. ${ }^{32}$

\section{High frequency of watching TV while eating}

The significant correlation between time spent on TV watching and BMI has been repeatedly shown since the eighties ${ }^{33-34}$ suggesting that increased levels of children's TV viewing increase the overweight epidemic among children. ${ }^{1,2}$ Similarly to our study, the GENESIS study $y^{35}$ found that children's BMI status, physical activity status, their maternal educational status and the region of residence were significantly associated with the time children spent in TV viewing.

Mother's age and child's BMI

Our study evidenced that mother's age and BMI significantly increase the risk of high BMI in preschoolers, which is consistent with previous studies in preschoolers, also revealing a higher prevalence of OW/OB in children with overweight/obese parents compared to their peers' parents with normal weight. ${ }^{7,36,37}$ Similarly, according to the GRECO Study ${ }^{5}$ and the Toy Box Study ${ }^{38}$ in preschoolers, mother's age was a protective predictor for both girls' and boys' $\mathrm{OW} / \mathrm{OB}$ status.

Parental smoking and alcohol consumption

Our study depicted the increased risk of high BMI in preschoolers whose parents are long-term smokers and alcohol consumers. In line with previous research, higher maternal alcohol consumption during pregnancy is associated with a slightly lower likelihood of 14-month-old infants following a relatively healthy dietary pattern. ${ }^{23}$ Maternal smoking during pregnancy or early infancy and paternal smoking during the prenatal period are predominantly associated with infants or children up to age 7 years following unhealthier diets and/or being less likely to adhere to healthier diets ${ }^{23}$.

\section{Eating out in fast food restaurants}

Eating outside home has been associated with higher intake of dietary fat and energy compared to home eating, and as frequency of eating at fast-food restaurants has increased, consumption of fruit, vegetables, and dairy has decreased. ${ }^{39}$ Our research study, also pointed out that the risk of obesity and high BMI score in children is elevated the more often they eat outside home, in fast food restaurants.

\section{Parental characteristics and habits decreasing risk of high BMI in preschoolers.}

Breakfast consumption as determinant of young children's BMI

Promoting breakfast eating among children is multi-beneficial, including improved cognitive and physical abilities, increased likelihood of meeting the recommendations for fruit and vegetable intake, and decreased unhealthy snacking. ${ }^{29}$ Our finding echoes those of the Greek PANACEA Study in 10-12-year-old Greek children, ${ }^{40}$ in which daily consumption of breakfast was also inversely associated with prevalence of OW/OB in both genders. ${ }^{41}$

Brunch and early dinner and their relation to preschoolers' BMI

Parental dynamics strongly influence the incidence and regularity of family meals having a protective effect in young children's BMI. ${ }^{42-43}$ Regular family meals are related with a lower risk of OW/OB, higher average of fruit and vegetable intake, lower fast food and soft drink consumption and an overall better diet quality. ${ }^{44}$ Our research demonstrated that brunch consumption and the latest time of dinner consumption are inversely associated with high BMI and occurrence of OW/OB in preschoolers, regardless of gender and ethnic background. According to a relevant review, ${ }^{44}$ significant associations between higher family meal frequency and better overall diet quality, less unhealthy diet and lower BMI were revealed. of BMI

Parental control of preschoolers' diet as determinant

Associations between parental structural strategies and child's lower BMI score and promotion of healthy eating are more frequently adopted at preschool age, while they seem to be of less value at older child ages probably due to the degree of child's independence..$^{45}$ Existing literature with low-income minority samples suggests that certain parental feeding 
practices, such as an indulgent feeding style, were associated with child overweight. ${ }^{46} \mathrm{~A}$ cross-sectional study of ethnically diverse, low-income preschoolers and their mothers ${ }^{47}$ exhibited that neither child race nor maternal pressure to eat and restriction were linked to child overweight based on child BMI.

\section{Predictors associated with preschoolers' KIDMED score}

Parental and children's frequency of following the Mediterranean diet are depicted, in our study, as positive predictors of preschoolers' higher KIDMED score. Similarly, the Greek Childhood Obesity (GRECO) study showed that children with higher KIDMED score presented more frequent consumption of foods sustaining the MD pattern (fruits, vegetables, legumes, dairy products, fish, bread, nuts) and a less frequent consumption of foods that undermine the MD scheme, and should be consumed in moderation or rarely. ${ }^{48}$ Moreover, breakfast consumption, the habit of having family meals during the week, and higher adherence of parents to the MD increased the odds of a child presenting higher KIDMED score. ${ }^{48}$ The adverse association between low adherence to the MD dietary patterns and a non-optimal KIDMED score was similarly addressed in another study of Greek children, ${ }^{49,50}$ as well as Cypriot children. ${ }^{51}$

\section{Study limitations}

The current findings should be discussed under some limitations and be carefully translated into further research and actions. Power analysis was not conducted since we addressed all active kindergartens and managed to have satisfying response rates. This may lead to underestimation of preschoolers BMI and should be taken into consideration. Additionally, no clinical and somatometric measurements were performed, since all data were self-reported; potentially hiding slight information or/and recall bias.

\section{Conclusions}

Parents, as nutritional gatekeepers, influence and shape, especially in the early years, their child's eating behavior both directly, through the food they prepare and consuming at home, and indirectly, through their behavior, attitudes and the nutritional environments they choose for their children inside, or outside home. The present findings could represent a stepping stone for the formulation of nominal early life obesity curbing family, as well as school-based interventions and public health policies in Greece.

\section{Declarations}

\section{Authors' contributions}

$\mathrm{MC}$ conceptualized and designed the study, formulated the research questions, carried out the study, drafted the article and revised it critically for important intellectual content and final approved the final version to be submitted. IT formulated the research questions, analyzed the data, drafted the article, revised it critically for important intellectual content and approved the final version to be submitted. DSP analyzed the data, drafted the article, revised it critically for important intellectual content and approved the submission of the final version. NT formulated the research questions, designed the study, reviewed the manuscript and approved the final version to be submitted.

Funding "This research did not receive any specific grant from funding agencies in the public, commercial, or not-for-profit sectors. Nevertheless, it was financially supported concerning printing and office supplies expenses by the Special Account for Research Funds of the Pneumonology Research Society of University of Crete".

„The authors declare no conflict of interest related to this publication".

\section{Acknowledgements}

The authors would like to address their gratitude to the directors, educators, children and their families of all the participating schools for their valuable cooperation in the realization of this study. We would, also, like to thank all the academic stuff from the Medical School, University of Crete, for their significant role in data analysis, interpretation and manuscript preparation, contribution in carrying out this study. All authors read and approved the final manuscript.

\section{REFEREnCES}

1. Organization WH. Report of the commission on ending childhood obesity. WHO Library Cataloguing-in-Publication Data 2016.

2. de Onis M, Blossner M, Borghi E. Global prevalence and trends of overweight and obesity among preschool children. Am J Clin Nutr 2010;92(5):1257-64.

3. Cattaneo A, Monasta L, Stamatakis E, et al. Overweight and obesity in infants and pre-school children in the European Union: a review of existing data. Obes Rev 2010;11(5):389-98.

4. Hassapidou M, Daskalou E, Tsofliou F, et al. Prevalence of overweight and obesity in preschool children in Thessaloniki, Greece. Hormones (Athens) 2015;14(4):615-22.

5. Farajian P, Panagiotakos DB, Risvas G, et al. Socio-economic and demographic determinants of childhood obesity prevalence in Greece: the GRECO (Greek Childhood Obesity) study. Public Health Nutr 2012;16(2):240-7.

6. Han JC, Lawlor DA, Kimm SY. Childhood obesity. Lancet 2010;375(9727):1737-48.

7. Manios Y, Costarelli V, Kolotourou M, Kondakis K, Tzavara C, Moschonis G. Prevalence of obesity in preschool Greek 
children, in relation to parental characteristics and region of residence. BMC Public Health 2007;7:178.

8. Serra-Majem L, Ribas L, Ngo J, et al. Food, youth and the Mediterranean diet in Spain. Development of KIDMED, Mediterranean Diet Quality Index in children and adolescents. Public Health Nutr 2004;7(7):931-5.

9. Manios Y. Design and descriptive results of the „Growth, Exercise and Nutrition Epidemiological Study In preSchoolers": the GENESIS study. BMC Public Health 2006;6:32.

10. Pereira-da-Silva L, Rego C, Pietrobelli A. The diet of preschool children in the Mediterranean countries of the European Union: a systematic review. Int J Environ Res Public Health 2016;13(6).

11. Ogden CL, Carroll MD, Curtin LR, Lamb MM, Flegal KM. Prevalence of high body mass index in US children and adolescents, 2007-2008. JAMA 2010;303(3):242-9.

12. Murashima M, Hoerr SL, Hughes SO, Kaplowitz SA. Feeding behaviors of low-income mothers: directive control relates to a lower BMI in children, and a nondirective control relates to a healthier diet in preschoolers. Am J Clin Nutr 2012;95(5):1031-7.

13. Hodges EA, Smith C, Tidwell S, Berry D. Promoting physical activity in preschoolers to prevent obesity: a review of the literature. J Pediatr Nurs 2013;28(1):3-19.

14. Trost SG, Fees B, Dzewaltowski D. Feasibility and efficacy of a "move and learn" physical activity curriculum in preschool children. J Phys Act Health 2008;5(1):88-103.

15. Manios Y, Kourlaba G, Kondaki K, Grammatikaki E, Anastasiadou A, Roma-Giannikou E. Obesity and television watching in preschoolers in Greece: the GENESIS study. Obesity (Silver Spring) 2009;17(11):2047-53.

16. Cox R, Skouteris H, Rutherford L, Fuller-Tyszkiewicz M, Dell' Aquila D, Hardy LL. Television viewing, television content, food intake, physical activity and body mass index: a cross-sectional study of preschool children aged $2-6$ years. Health Promot J Austr 2012;23(1):58-62.

17. Manios Y, Moschonis G, Grammatikaki E, Anastasiadou A, Liarigkovinos T. Determinants of childhood obesity and association with maternal perceptions of their children's weight status: the „GENESIS“ study. J Am Diet Assoc 2010;110(10):1527-31.

18. Dev DA, McBride BA, Fiese BH, Jones BL, Cho H. Risk factors for overweight/obesity in preschool children: an ecological approach. Child Obes 2013;9(5):399-408.

19. Carlson E, Kipps M, Thomson J. Influences on the food habits of some ethnic minorities in the United Kingdom. Hum Nutr Appl Nutr 1984;38(2):85-98.

20. Stronks K, Kulu-Glasgow I, Agyemang C. The utility of 'country of birth' for the classification of ethnic groups in health research: the Dutch experience. Ethn Health 2009; 14(3):255-69.

21. Antonogeogros G, Grigoropoulou D, Papadimitriou A, et al. Validation of a Food Frequency Questionnaire designed for children 10-12 years: the Panacea-FFQ. Pediatric Research 2011;70:778-. .

22. Leventakou V, Georgiou V, Chatzi L, Sarri K. Relative validity of an FFQ for pre-school children in the mother-child 'Rhea' birth cohort in Crete, Greece. Public Health Nutr 2014;18(3):421-7.

23. Chatzi L, Leventakou V, Vafeiadi M, et al. Cohort profile: the mother-child cohort in Crete, Greece (Rhea Study). Int J Epidemiol 2017;46(5):1392-3k.

24. Ventura AK, Birch LL. Does parenting affect children's eating and weight status? Int J Behav Nutr Phys Act 2008;5:15.

25. Faith MS, Scanlon KS, Birch LL, Francis LA, Sherry B. Parent-child feeding strategies and their relationships to child eating and weight status. Obes Res 2004;12(11):1711-22.
26. Reilly JJ. Physical activity, sedentary behaviour and energy balance in the preschool child: opportunities for early obesity prevention. Proc Nutr Soc 2008;67(3):317-25.

27. Trost SG, Sirard JR, Dowda M, Pfeiffer KA, Pate RR. Physical activity in overweight and nonoverweight preschool children. Int J Obes Relat Metab Disord 2003;27(7):834-9.

28. Cho S, Dietrich M, Brown CJ, Clark CA, Block G. The effect of breakfast type on total daily energy intake and body mass index: results from the Third National Health and Nutrition Examination Survey (NHANES III). J Am Coll Nutr 2003;22(4):296-302.

29. Antonogeorgos G, Panagiotakos DB, Papadimitriou A, Priftis KN, Anthracopoulos M, Nicolaidou P. Breakfast consumption and meal frequency interaction with childhood obesity. Pediatr Obes 2011;7(1):65-72.

30. Sotos-Prieto M, Santos-Beneit G, Pocock S, Redondo J, Fuster V, Penalvo JL. Parental and self-reported dietary and physical activity habits in pre-school children and their socio-economic determinants. Public Health Nutr 2014;18(2):275-85.

31. Janz KF, Levy SM, Burns TL, Torner JC, Willing MC, Warren JJ. Fatness, physical activity, and television viewing in children during the adiposity rebound period: the Iowa Bone Development Study. Prev Med 2002;35(6):563-71.

32. Farajian P Z. A Mediterranean diet in children and adolescents. In: Preedy VR, Watson RR (eds) The Mediterranean diet: an evidence-based approach 2014 (Elsevier, London):69-80.

33. Christakis DA, Ebel BE, Rivara FP, Zimmerman FJ. Television, video, and computer game usage in children under 11 years of age. J Pediatr 2004;145(5):652-6.

34. Amigo-Vázquez I, Errasti-Pérez JM, Peña-Suárez E. Skipping breakfast, sedentarism and overweight in children. Psychology, Health $\mathbb{E}$ Medicine 2016;21(7):819-26.

35. Kourlaba G, Kondaki K, Liarigkovinos T, Manios Y. Factors associated with television viewing time in toddlers and preschoolers in Greece: the GENESIS study. J Public Health (Oxf) 2009;31(2):222-30.

36. Whitaker KL, Jarvis MJ, Beeken RJ, Boniface D, Wardle J. Comparing maternal and paternal intergenerational transmission of obesity risk in a large population-based sample. Am J Clin Nutr 2010;91(6):1560-7.

37. Manios Y, Androutsos O, Katsarou C, et al. Prevalence and sociodemographic correlates of overweight and obesity in a large Pan-European cohort of preschool children and their families: the ToyBox study. Nutrition 2018;55-56:192-8.

38. Cadenas-Sanchez C, Nystrom C, Sanchez-Delgado G, et al. Prevalence of overweight/obesity and fitness level in preschool children from the north compared with the south of Europe: an exploration with two countries. Pediatr Obes 2015;11(5):403-10.

39. Braithwaite I, Stewart AW, Hancox RJ, Beasley R, Murphy R, Mitchell EA. Fast-food consumption and body mass index in children and adolescents: an international cross-sectional study. BMJ Open 2014;4(12):e005813.

40. Panagiotakos D, Antonogeorgos G, Papadimitriou A, et al. Breakfast cereal is associated with a lower prevalence of obesity among 10e12-year-old children: The PANACEA study. Nutrition, Metabolism \& Cardiovascular Diseases 2008;18:606-12.

41. Affenito SG, Thompson DR, Barton BA, et al. Breakfast consumption by African-American and white adolescent girls correlates positively with calcium and fiber intake and negatively with body mass index. J Am Diet Assoc 2005;105(6):938-45. 
42. Berge JM, MacLehose RF, Loth KA, Eisenberg ME, Fulkerson JA, Neumark-Sztainer D. Family meals. Associations with weight and eating behaviors among mothers and fathers. Appetite 2012;58(3):1128-35.

43. Blissett J, Bennett C, Fogel A, Harris G, Higgs S. Parental modelling and prompting effects on acceptance of a novel fruit in 2-4-year-old children are dependent on children's food responsiveness. Br J Nutr 2016;115(3):554-64.

44. Dallacker M, Hertwig R, Mata J. The frequency of family meals and nutritional health in children: a meta-analysis. Obes Rev 2018;19(5):638-53.

45. Warkentin S, Mais LA, Latorre M, Carnell S, de Aguiar CarrazedoTaddei JA. Parents matter: associations of parental BMI and feeding behaviors with child BMI in Brazilian preschool and school-aged children. Frontiers in Nutrition 2018;5(69).

46. Hughes SO, Power TG, Orlet Fisher J, Mueller S, Nicklas TA. Revisiting a neglected construct: parenting styles in a child-feeding context. Appetite 2005;44(1):83-92
47. May AL, Donohue M, Scanlon KS, et al. Child-feeding strategies are associated with maternal concern about children becoming overweight, but not children's weight status. J Am Diet Assoc 2007;107(7):1167-75.

48. Farajian P, Risvas G, Karasouli K, et al. Very high childhood obesity prevalence and low adherence rates to the Mediterranean diet in Greek children: the GRECO study. Atherosclerosis 2011;217(2):525-30.

49. Kontogianni MD, Farmaki AE, Vidra N, Sofrona S, Magkanari F, Yannakoulia M. Associations between lifestyle patterns and body mass index in a sample of Greek children and adolescents. J Am Diet Assoc 2010;110(2):215-21.

50. Kontogianni MD, Vidra N, Farmaki AE, et al. Adherence rates to the Mediterranean diet are low in a representative sample of Greek children and adolescents. J Nutr 2008;138(10):1951-6.

51. Lazarou C, Panagiotakos DB, Matalas AL. Level of adherence to the Mediterranean diet among children from Cyprus: the CYKIDS study. Public Health Nutr 2009;12(7):991-1000.

\section{Appendix}

Table S1: Comparison of parents' dietary habits between ethnicity groups $(n=578)$

\begin{tabular}{|c|c|c|c|}
\hline & \multicolumn{2}{|c|}{$\begin{array}{l}\text { Nationality } \\
\quad \mathrm{N}(\%)\end{array}$} & \multirow[t]{2}{*}{$P$ value } \\
\hline & $\begin{array}{l}\text { Greeks } \\
N=451\end{array}$ & $\begin{array}{c}\text { Other } \\
\text { nationality } \\
\mathrm{N}=127\end{array}$ & \\
\hline $\begin{array}{l}\text { Aware of } \\
\text { Mediterranean diet's } \\
\text { principles }\end{array}$ & & & $<0.001$ \\
\hline Not sure & $59(13.1)$ & $42(18.9)$ & \\
\hline Not aware & $7(1.6)$ & $24(18.9)$ & \\
\hline Aware & $385(85.4)$ & $61(48.0)$ & \\
\hline $\begin{array}{l}\text { Frequency of } \\
\text { Mediterranean diet }\end{array}$ & & & $<0.001$ \\
\hline Not at all & $13(2.9)$ & $25(19.8)$ & \\
\hline Rarely & $83(18.5)$ & $53(42.1)$ & \\
\hline Often & $314(70.1)$ & $45(35.7)$ & \\
\hline Very often & $38(8.5)$ & $3(2.4)$ & \\
\hline $\begin{array}{l}\text { Breakfast consump- } \\
\text { tion (yes) }\end{array}$ & $342(75.8)$ & $91(71.7)$ & 0.3 \\
\hline $\begin{array}{l}\text { Brunch consump- } \\
\text { tion (yes) }\end{array}$ & $301(67.2)$ & $44(34.6)$ & $<0.001$ \\
\hline $\begin{array}{l}\text { Meal consumption } \\
\text { (yes) }\end{array}$ & $425(94.7)$ & $122(96.1)$ & 0.5 \\
\hline $\begin{array}{l}\text { Consumption of } \\
\text { meal in the after- } \\
\text { noon (yes) }\end{array}$ & $254(56.3)$ & $55(43.3)$ & 0.009 \\
\hline $\begin{array}{l}\text { Dinner consump- } \\
\text { tion (yes) }\end{array}$ & 357 (79.2) & $111(87.4)$ & 0.03 \\
\hline $\begin{array}{l}\text { Consumption of } \\
\text { meal overnight (yes) }\end{array}$ & $14(3.1)$ & $4(3.1)$ & 0.9 \\
\hline Time of dinner & & & 0.2 \\
\hline Don't eat & $42(9.3)$ & $8(6.3)$ & \\
\hline
\end{tabular}

Table S1: Comparison of parents' dietary habits between ethnicity groups $(n=578)$ (continued)

\begin{tabular}{|c|c|c|c|}
\hline & \multicolumn{2}{|c|}{$\begin{array}{l}\text { Nationality } \\
\quad \mathrm{N}(\%)\end{array}$} & \multirow[t]{2}{*}{$P$ value } \\
\hline & $\begin{array}{l}\text { Greeks } \\
\mathrm{N}=451\end{array}$ & $\begin{array}{c}\text { Other } \\
\text { nationality } \\
\mathrm{N}=127\end{array}$ & \\
\hline Not at specific time & $74(16.4)$ & $28(22)$ & \\
\hline Before 20.00 & $70(15.5)$ & $28(22)$ & \\
\hline At 20.00 & $87(19.3)$ & $20(15.7)$ & \\
\hline At 21.00 & $125(27.7)$ & $35(27.6)$ & \\
\hline At 22.00 & $44(9.8)$ & $7(5.5)$ & \\
\hline After 22.00 & $9(2.0)$ & $1(0.8)$ & \\
\hline $\begin{array}{l}\text { Reasons for food } \\
\text { consumption }\end{array}$ & & & $<0.001$ \\
\hline Mainly for pleasure & $30(6.7)$ & $24(18.9)$ & \\
\hline Mainly for survival & $50(11.1)$ & $13(10.2)$ & \\
\hline Both & $365(80.9)$ & $83(65.4)$ & \\
\hline None & $6(1.3)$ & $7(5.5)$ & \\
\hline $\begin{array}{l}\text { Frequency of } \\
\text { out-home meal }\end{array}$ & & & $<0.001$ \\
\hline Never & $10(2.2)$ & $12(9.4)$ & \\
\hline Rarely per year & $209(46.4)$ & $70(55.1)$ & \\
\hline Rarely per month & $204(45.3)$ & $37(29.1)$ & \\
\hline Rarely per week & $26(5.8)$ & $4(3.1)$ & \\
\hline Every day & $1(0.2)$ & $4(3.1)$ & \\
\hline $\begin{array}{l}\text { Frequency of eating } \\
\text { at restaurants }\end{array}$ & & & $<0.001$ \\
\hline Never & $33(7.3)$ & $45(35.4)$ & \\
\hline Rarely & $244(54.2)$ & $64(50.4)$ & \\
\hline Often & $173(38.4)$ & $18(14.2)$ & \\
\hline
\end{tabular}


Table S1: Comparison of parents' dietary habits between ethnicity groups $(\mathrm{n}=578)$ (continued)

\begin{tabular}{|c|c|c|c|}
\hline & \multicolumn{2}{|c|}{$\begin{array}{l}\text { Nationality } \\
\quad \mathrm{N}(\%)\end{array}$} & \multirow[t]{2}{*}{$P$ value } \\
\hline & $\begin{array}{l}\text { Greeks } \\
\mathrm{N}=451\end{array}$ & $\begin{array}{c}\text { Other } \\
\text { nationality } \\
\mathrm{N}=127\end{array}$ & \\
\hline $\begin{array}{l}\text { Frequency of eating } \\
\text { at fast food restau- } \\
\text { rants (including } \\
\text { souvlakery) }\end{array}$ & & & $<0.001$ \\
\hline Never & $104(23.2)$ & $58(45.7)$ & \\
\hline Rarely & $263(58.6)$ & $58(45.7)$ & \\
\hline Often & $82(18.3)$ & $11(8.7)$ & \\
\hline $\begin{array}{l}\text { Frequency of eating } \\
\text { at "ouzeri" }\end{array}$ & & & $<0.001$ \\
\hline Never & $244(54.3)$ & $113(89)$ & \\
\hline Rarely & $157(35)$ & $12(9.4)$ & \\
\hline Often & $48(10.7)$ & $2(1.6)$ & \\
\hline $\begin{array}{l}\text { Frequency of eating } \\
\text { at pizza restaurants }\end{array}$ & & & 0.4 \\
\hline Never & $305(68.1)$ & $93(73.8)$ & \\
\hline Rarely & $125(27.9)$ & $30(23.8)$ & \\
\hline Often & $18(4)$ & $3(2.4)$ & \\
\hline $\begin{array}{l}\text { Frequency of order- } \\
\text { ing from delivery }\end{array}$ & & & 0.01 \\
\hline Never & $143(31.7)$ & $67(52.8)$ & \\
\hline Once per week & $63(14.1)$ & $12(9.5)$ & \\
\hline Twice per week & $6(1.3)$ & $1(0.8)$ & \\
\hline Once/Twice per month & $239(53)$ & $47(37)$ & \\
\hline $\begin{array}{l}\text { Frequency of home- } \\
\text { made food consump- } \\
\text { tion }\end{array}$ & & & 0.01 \\
\hline
\end{tabular}

Table S2: Comparison of preschoolers' dietary habits between ethnicity groups $(\mathrm{n}=578)$

\begin{tabular}{|c|c|c|c|}
\hline & \multicolumn{2}{|c|}{$\begin{array}{l}\text { Nationality } \\
\mathrm{N}(\%)\end{array}$} & \multirow[t]{2}{*}{ P value } \\
\hline & $\begin{array}{l}\text { Greeks } \\
\mathrm{N}=451\end{array}$ & $\begin{array}{c}\text { Other } \\
\text { nationality } \\
N=127\end{array}$ & \\
\hline $\begin{array}{c}\text { Consumption of } \\
\text { breakfast }\end{array}$ & & & 0.08 \\
\hline No & $40(8.9)$ & $18(14.2)$ & \\
\hline Yes & 409 (91.1) & $109(85.8)$ & \\
\hline $\begin{array}{c}\text { Consumption of } \\
\text { brunch }\end{array}$ & & & $<0.001$ \\
\hline No & $26(5.8)$ & $22(17.3)$ & \\
\hline Yes & $425(94.2)$ & $105(82.7)$ & \\
\hline $\begin{array}{c}\text { Consumption of } \\
\text { lunch }\end{array}$ & & & 0.4 \\
\hline No & $1(0.2)$ & $1(0.8)$ & \\
\hline Yes & $449(99.8)$ & $126(99.2)$ & \\
\hline $\begin{array}{l}\text { Consumption } \\
\text { of meal in the } \\
\text { afternoon }\end{array}$ & & & $<0.001$ \\
\hline No & $56(12.4)$ & $41(32.3)$ & \\
\hline
\end{tabular}

Table S1: Comparison of parents' dietary habits between ethnicity groups $(n=578)$ (continued)

\begin{tabular}{|c|c|c|c|}
\hline & \multicolumn{2}{|c|}{$\begin{array}{l}\text { Nationality } \\
\quad \mathrm{N}(\%)\end{array}$} & \multirow[t]{2}{*}{$\mathrm{P}$ value } \\
\hline & $\begin{array}{l}\text { Greeks } \\
\mathrm{N}=451\end{array}$ & $\begin{array}{c}\text { Other } \\
\text { nationality } \\
\mathrm{N}=127\end{array}$ & \\
\hline Once/twice per week & $2(0.4)$ & $5(3.9)$ & \\
\hline $\begin{array}{l}\text { Three/four times per } \\
\text { week }\end{array}$ & $61(13.5)$ & $20(15.7)$ & \\
\hline Every day & $388(86)$ & $102(80.3)$ & \\
\hline $\begin{array}{l}\text { Frequency of veg- } \\
\text { etables and fruits } \\
\text { consumption }\end{array}$ & & & 0.01 \\
\hline $\begin{array}{l}\text { Less than once per } \\
\text { week }\end{array}$ & 7 (1.6) & - & \\
\hline At least once per week & $41(9.1)$ & $6(4.7)$ & \\
\hline $\begin{array}{l}\text { Three/five times per } \\
\text { week }\end{array}$ & $151(33.5)$ & $31(24.4)$ & \\
\hline Every day & $252(55.9)$ & $90(70.9)$ & \\
\hline $\begin{array}{l}\text { Aware of number of } \\
\text { optimum consump- } \\
\text { tion of vegetables } \\
\text { and fruits }\end{array}$ & & & $<0.001$ \\
\hline No & $129(28.7)$ & $57(45.2)$ & \\
\hline Yes & $321(71.3)$ & $69(54.8)$ & \\
\hline $\begin{array}{l}\text { Number of optimum } \\
\text { consumption of veg- } \\
\text { etables and fruits }\end{array}$ & & & $<0.001$ \\
\hline 1 part per week & $1(0.3)$ & $1(1.4)$ & \\
\hline 1 part per day & $75(22.9)$ & $38(51.4)$ & \\
\hline 3 parts per day & $155(47.4)$ & $24(32.4)$ & \\
\hline 5 parts per day & $96(29.4)$ & $11(14.9)$ & \\
\hline
\end{tabular}

Table S2: Comparison of preschoolers' dietary habits between ethnicity groups $(n=578)$ (continued)

\begin{tabular}{|c|c|c|c|}
\hline & \multicolumn{2}{|c|}{$\begin{array}{c}\text { Nationality } \\
\mathrm{N}(\%)\end{array}$} & \multirow[t]{2}{*}{ P value } \\
\hline & $\begin{array}{l}\text { Greeks } \\
\mathrm{N}=451\end{array}$ & $\begin{array}{c}\text { Other } \\
\text { nationality } \\
\mathrm{N}=127\end{array}$ & \\
\hline Yes & $395(87.6)$ & $86(67.7)$ & \\
\hline $\begin{array}{c}\text { Consumption of } \\
\text { dinner }\end{array}$ & & & 0.7 \\
\hline No & $47(10.4)$ & $12(9.4)$ & \\
\hline Yes & $404(89.6)$ & $115(90.6)$ & \\
\hline $\begin{array}{l}\text { Consumption of } \\
\text { other additional } \\
\text { meals }\end{array}$ & & & 0.4 \\
\hline No & $418(92.9)$ & $115(90.6)$ & \\
\hline Yes & $32(7.1)$ & $12(9.4)$ & \\
\hline $\begin{array}{l}\text { Time of dinner } \\
\text { consumption }\end{array}$ & & & $<0.001$ \\
\hline No dinner & $19(4.2)$ & $2(1.6)$ & \\
\hline No specific hour & $18(4)$ & $18(14.2)$ & \\
\hline Before 20.00 & $144(31.9)$ & $48(37.8)$ & \\
\hline
\end{tabular}


Table S2: Comparison of preschoolers' dietary habits between ethnicity groups $(\mathrm{n}=578)$ (continued)

\begin{tabular}{|c|c|c|c|}
\hline & \multicolumn{2}{|c|}{$\begin{array}{l}\text { Nationality } \\
\text { N (\%) }\end{array}$} & \multirow[t]{2}{*}{$P$ value } \\
\hline & $\begin{array}{l}\text { Greeks } \\
\mathrm{N}=451\end{array}$ & $\begin{array}{c}\text { Other } \\
\text { nationality } \\
\mathrm{N}=127\end{array}$ & \\
\hline At 20.00 & $193(42.8)$ & $44(34.6)$ & \\
\hline At 21.00 & $70(15.5)$ & $13(10.2)$ & \\
\hline At 22.00 & $7(1.6)$ & $2(1.6)$ & \\
\hline $\begin{array}{l}\text { Breakfast fre- } \\
\text { quency at kinder- } \\
\text { garten }\end{array}$ & & & $<0.001$ \\
\hline $1-2$ days & $27(6)$ & $18(14.2)$ & \\
\hline 3-4 days & $154(34.3)$ & $51(40.2)$ & \\
\hline 5 days & $235(52.3)$ & $39(30.7)$ & \\
\hline Skips breakfast & $33(7.3)$ & $19(15)$ & \\
\hline $\begin{array}{c}\text { Frequency of } \\
\text { eating at fast food } \\
\text { restaurants }\end{array}$ & & & 0.4 \\
\hline $\begin{array}{c}4 \text { or more times per } \\
\text { week }\end{array}$ & $3(0.7)$ & $2(1.6)$ & \\
\hline $2-3$ times per week & $4(0.9)$ & $1(0.8)$ & \\
\hline Once per week & $76(16.9)$ & $16(12.6)$ & \\
\hline $1-3$ times per month & $162(35.9)$ & $47(37)$ & \\
\hline $\begin{array}{c}\text { Less than once per } \\
\text { month }\end{array}$ & $180(39.9)$ & $48(37.8)$ & \\
\hline Never & $26(5.8)$ & $13(10.2)$ & \\
\hline $\begin{array}{l}\text { Parents control- } \\
\text { ling child's diet }\end{array}$ & & & 0.01 \\
\hline Never & $2(0.4)$ & $3(2.4)$ & \\
\hline Rarely & $6(1.3)$ & $6(4.8)$ & \\
\hline Relatively often & $49(10.9)$ & $20(15.9)$ & \\
\hline Often & $199(44.1)$ & $49(38.9)$ & \\
\hline Very often & $195(43.2)$ & $48(38.1)$ & \\
\hline $\begin{array}{l}\text { Frequency of veg- } \\
\text { etables or fruits } \\
\text { consumption }\end{array}$ & & & $<0.001$ \\
\hline Not at all & $63(14)$ & $9(7.1)$ & \\
\hline Once per day & $323(71.6)$ & $82(64.6)$ & \\
\hline 2.3 times per day & $54(12)$ & $27(21.3)$ & \\
\hline $\begin{array}{c}\text { More than } 3 \text { times } \\
\text { per day }\end{array}$ & $11(2.4)$ & $9(7.1)$ & \\
\hline $\begin{array}{l}\text { If child refuses } \\
\text { consumption: }\end{array}$ & & & 0.3 \\
\hline Don't insist & $166(36.9)$ & $50(39.7)$ & \\
\hline Insist & $237(52.7)$ & $58(46)$ & \\
\hline Offers alternative & $47(10.4)$ & $18(14.3)$ & \\
\hline $\begin{array}{l}\text { Informed about } \\
\text { food labeling }\end{array}$ & & & 0.6 \\
\hline Not at all & $22(4.9)$ & $11(8.7)$ & \\
\hline A little & $85(18.8)$ & $24(18.9)$ & \\
\hline So and so & $170(37.7)$ & $45(35.4)$ & \\
\hline Enough & $143(31.7)$ & $38(29.9)$ & \\
\hline A lot & $31(6.9)$ & $9(7.1)$ & \\
\hline $\begin{array}{l}\text { Allergy in specific } \\
\text { food/products }\end{array}$ & & & 0.04 \\
\hline
\end{tabular}

Table S2: Comparison of preschoolers' dietary habits between ethnicity groups $(\mathrm{n}=578)$ (continued)

\begin{tabular}{|c|c|c|c|}
\hline & \multicolumn{2}{|c|}{$\begin{array}{l}\text { Nationality } \\
\text { N (\%) }\end{array}$} & \multirow[t]{2}{*}{ P value } \\
\hline & $\begin{array}{l}\text { Greeks } \\
\mathrm{N}=451\end{array}$ & $\begin{array}{c}\text { Other } \\
\text { nationality } \\
\mathrm{N}=127\end{array}$ & \\
\hline No & $434(96.2)$ & $117(92.1)$ & \\
\hline
\end{tabular}

Parents' assess-
ment of child's
weight

weight

\begin{tabular}{|c|c|c|c|}
\hline More than normal & $24(5.3)$ & $7(5.5)$ & \\
\hline Normal & $364(80.9)$ & $105(82.7)$ & \\
\hline Less than normal & $62(13.8)$ & $15(11.8)$ & \\
\hline $\begin{array}{l}\text { Parents' assess- } \\
\text { ment of child's } \\
\text { amount of food } \\
\text { consumption }\end{array}$ & & & 0.04 \\
\hline Eats too little & $5(1.1)$ & $6(4.7)$ & \\
\hline Eats little & $72(16)$ & $25(19.7)$ & \\
\hline $\begin{array}{c}\text { Eats normal } \\
\text { amounts }\end{array}$ & $341(75.6)$ & $87(68.5)$ & \\
\hline
\end{tabular}

Eats more than $31(6.9) \quad 8(6.3)$

Eats too much $\quad 2(0.4) \quad 1(0.5)$

\begin{tabular}{cccc}
\hline Eats too much & $2(0.4)$ & $1(0.5)$ & \\
\hline $\begin{array}{c}\text { Child under diet } \\
\text { during the last } \\
\text { year }\end{array}$ & & & 0.8 \\
\hline No & $441(98)$ & $124(97.6)$ & \\
\hline Yes & $9(2)$ & $3(2.4)$ \\
\hline
\end{tabular}

\begin{tabular}{|c|c|c|c|}
\hline $\begin{array}{l}\text { Reason of child } \\
\text { being under diet }\end{array}$ & & & 0.5 \\
\hline Loosing weight & $3(33.3)$ & - & \\
\hline Gaining weight & $2(22.2)$ & $1(33.3)$ & \\
\hline Medical reasons & $4(44.4)$ & $2(66.7)$ & \\
\hline
\end{tabular}

\section{Removing fat}

from child's meat

(prior consump-

0.02

\begin{tabular}{cccc} 
tion) & & & \\
\hline No & $72(16)$ & $32(25.2)$ & \\
\hline Yes & $379(84)$ & $95(74.8)$ & \\
\hline $\begin{array}{c}\text { Type of oil used } \\
\text { for cooking }\end{array}$ & & & $<0.001$ \\
\hline Olive oil & $447(99.1)$ & $117(92.1)$ & \\
\hline Seed oil & $2(0.4)$ & $5(3.9)$ & \\
\hline Butter & - & $2(1.6)$ & \\
\hline Margarine & $2(0.4)$ & $3(2.4)$ &
\end{tabular}

\begin{tabular}{|c|c|c|c|}
\hline $\begin{array}{l}\text { Consumption of } \\
\text { food supplements } \\
\text { or vitamins }\end{array}$ & & & 0.01 \\
\hline No & $387(85.8)$ & $114(89.8)$ & \\
\hline Yes & $64(14.2)$ & $13(10.2)$ & \\
\hline $\begin{array}{l}\text { Change in buying } \\
\text { food products } \\
\text { during last year }\end{array}$ & & & 0.3 \\
\hline No & $229(50.9)$ & $58(45.7)$ & \\
\hline $\begin{array}{l}\text { Yes (main reason: } \\
\text { products prizes) }\end{array}$ & $221(49.1)$ & $69(54.3)$ & \\
\hline
\end{tabular}

